\title{
PRSS1 wt Allele
}

National Cancer Institute

\section{Source}

National Cancer Institute. PRSS1 wt Allele. NCI Thesaurus. Code C113758.

Human PRSS1 wild-type allele is located in the vicinity of 7q34 and is approximately $4 \mathrm{~kb}$ in length. This allele, which encodes trypsin-1 protein, plays a role in proteolysis and digestion. Mutations in this gene are associated with both hereditary pancreatitis and trypsinogen deficiency. 